\title{
Rhinoceros ownership and attitudes towards legalization of global horn trade within South Africa's private wildlife sector
}

\author{
Elena C. Rubino and Elizabeth F. PienaAR
}

\begin{abstract}
South Africa's private sector is vital to rhino conservation yet there is a lack of research into the attitudes of current and potential rhino owners towards rhino conservation and horn trade. We surveyed 169 members of the South African private wildlife ranching industry to examine these matters. We sought to understand: (1) ranchers' motivations for owning or not owning rhinos, (2) how rhino ownership affects ranchers' income and operations, and (3) the attitudes of wildlife industry members towards legalization of global rhino horn trade. Our findings indicate that all respondents recognize the risks of rhino ownership and tend to distrust national and provincial environmental departments. In addition to these concerns, rhino owners have substantial monthly security and management expenditures. We found positive attitudes overall towards global rhino horn trade. Rhino owners strongly agreed that legalization would benefit rhino owners and rhino conservation. Documenting the realities of private rhino ownership and the opinions of the wildlife industry is important for policy design and for informed debate about the legalization of the rhino horn trade.
\end{abstract}

Keywords Conservation policy, horn trade, rhinoceros, South Africa, surveys, wildlife conservation, wildlife markets

Supplementary material for this article is available at https://doi.org/10.1017/So030605318000030

\section{Introduction}

The black Diceros bicornis and white Ceratotherium I simum rhinoceros (hereafter, 'rhino') populations across Africa continue to be threatened by poaching, fuelled by Asian demand for rhino horn (Ferreira et al., 2014; Collins et al., 2016). Increased poaching has stimulated debate about the efficacy of the CITES global rhino horn trade ban in protecting rhinos, and whether the trade ban should

ElEna C. Rubino (Corresponding author) School of Natural Resources and the Environment, University of Florida, 103 Black Hall, PO Box 116455, Gainesville, Florida 32611, USA. E-mail elenacrubino@ufl.edu

Elizabeth F. Pienaar Department of Wildlife Ecology and Conservation, University of Florida, USA

Received 10 October 2017. Revision requested 22 November 2017. Accepted 11 January 2018. First published online 13 August 2018. be overturned (Biggs et al., 2013; Ferreira et al., 2014). Much of this debate has been abstract. The opinions of private wildlife ranchers, and their willingness to participate in horn trade, have been largely overlooked despite the fact that these individuals protect a third of the remaining South African rhino population (Rademeyer, 2016).

South Africa's private wildlife ranching sector, grounded in the sustainable use approach to wildlife management, has been vital to rhino conservation efforts (Child, 2012). However, increased poaching pressures have resulted in escalating costs of rhino ownership, in particular security costs to protect rhinos from poaching (Ferreira et al., 2014; Collins et al., 2016). It has been asserted that these costs outweigh the financial returns of rhino ownership (Child, 2012), thereby forcing wildlife ranchers to remove rhinos from their lands (Ferreira et al., 2014) and undermining rhino conservation in South Africa.

In April 2017 private rhino owners were granted the right to commercially trade horn within South Africa (Jones, 2017 b), a policy decision that is consistent with the sustainable use paradigm in South Africa. The intention is that private rhino owners may earn sufficient revenue from domestic trade in rhino horn to offset the security and management costs associated with rhino ownership (Jones, 2017a), thereby allowing private ranchers to continue financing rhino conservation on their lands. Whether the domestic trade will be sufficient to offset the costs of rhino ownership remains unclear because the demand for horn is primarily from Asia, and international trade in rhino horn remains banned (Ferreira et al., 2014). The Private Rhino Owners Association has advocated the implementation of global horn trade (Jones, 2017a, b).

There is little peer-reviewed evidence of private ranchers' attitudes towards rhino conservation, and how they could be assisted in conserving rhinos. There is also little evidence of the costs of rhino ownership, despite claims (Ferreira et al., 2014; Collins et al., 2016) that the costs of rhino ownership exceed the revenues that can be earned. To the best of our knowledge there have been only two relevant peer-reviewed studies of rhino owners and land managers (Wright et al., 2016; Rubino \& Pienaar, 2018). The lack of research into the realities of private rhino ownership probably stems from private ranchers' distrust of conservation organizations (Wright et al., 2016) and their unwillingness to share sensitive data for fear of information leaks and associated poaching threats (Davies-Mostert, 2014). Moreover, the 
private wildlife ranching community in South Africa tends to avoid participating in scientific research, to maintain their autonomy (Davies-Mostert, 2014), despite the potential benefits of such research to their livelihoods and conservation on their lands. As a result, there have been relatively few attempts to investigate the degree to which the private wildlife ranching sector engages in conservation and stewardship activities, or their motivations (van der Waal \& Dekker, 2000; Lindsey et al., 2006; Cousins et al., 2008; Taylor et al., 2015; Pienaar et al., 2017). To examine this matter and to understand better whether legalizing the horn trade could be expected to incentivize rhino conservation on private lands, we surveyed wildlife ranching industry members to (1) obtain a better understanding of their motivations for owning rhinos, (2) investigate how rhino ownership affects their income and operations, and (3) explore their attitudes towards the legalization of global horn trade.

\section{Methods}

\section{Survey design}

An electronic survey was administered to members of the South African private wildlife ranching industry during February-April 2017 (Supplementary Material 1). The survey was designed to elicit respondents' opinions about how legalization of global trade in rhino horn could impact rhino conservation. One of the major objections to removing the CITES ban on global horn trade is that this would result in intensive rhino farming, which is inconsistent with rhino conservation on extensive areas of native habitat (Wright et al., 2016). Accordingly, we asked respondents for their opinion about intensive rhino farming and whether ranchers who participate in the trade of rhino horn should be required to own a minimum amount of land per rhino. Respondents were also asked a series of questions related to their wildlife operation, including the activities in which they participate (e.g. hunting, wildlife breeding, photographic tourism, wildlife meat production) and the amount and location of the land they manage.

Questions that could be considered sensitive were placed after these initial questions, to reduce respondents' scepticism about the motivations for the survey (de Leeuw et al., 2008). We asked respondents if they currently own rhinos, to which they could provide three responses: yes, no, or I prefer not to answer. The latter option was included because rhino ownership is a sensitive topic (Davies-Mostert, 2014; Wright et al., 2016), and we wanted to encourage participants to answer truthfully so as not to bias our findings (de Leeuw et al., 2008). Rhino owners were asked about expenses and risks associated with rhino ownership, and the reasons they owned rhinos. Non-rhino owners and respondents who preferred not to state whether they owned rhinos were asked to state their concerns related to rhino ownership, and whether they owned rhinos in the past. All respondents were asked about their trust in South Africa's Department of Environmental Affairs and provincial environmental departments. These government agencies are relevant to rhino management and the trade in rhino horn, and qualitative interviews with rhino owners (conducted as part of the survey design process) indicated concerns that interactions with government agencies (e.g. applying for dehorning permits) may lead to poaching incidents. Respondents were also asked whether they were concerned that land reform would negatively affect their wildlife operations. We included these questions because social trust and government policies may affect wildlife ranchers' decision-making (see Davies-Mostert, 2014).

\section{Survey implementation}

Our study population included any individual who participated in a private wildlife-based operation in South Africa. We pre-tested our survey, using cognitive testing (Alaimo et al., 1999), at the January 2017 Dallas Safari Club convention with members of the study population, specifically South African professional hunters and wildlife ranchers. The survey, which was available in both English and Afrikaans, was distributed through several channels. (1) We attended the Safari Club International convention in Las Vegas, USA, in February 2017, to meet hunting outfitters and hand out flyers about the survey, and generated a list of these outfitters and sent them an email invitation, after the convention, to participate in the survey. (2) The Professional Hunters' Association of South Africa and the South African Hunters and Game Conservation Association included a link to the survey in their newsletters. (3) We directly contacted members of the Professional Hunters' Association, using the Association's online membership list. (4) We compiled our own list of potential respondents by conducting an Internet search using the keywords 'wildlife ranching', 'game ranching' and 'game hunting' for each of the nine South African provinces. (5) We used advertisements in recent issues of the Wildlife Ranching South Africa magazine to identify additional respondents. (6) Some respondents recommended we contact colleagues in the wildlife industry who would be interested in our research; this referral-based sampling (Biernacki \& Waldorf, 1981) increased our total number of completed surveys.

We made follow-up phone calls to all individuals who were initially contacted via email, if their phone numbers were publicly available. The majority of responses were collected online via Qualtrics survey software (Qualtrics LLC, Provo, USA), but some respondents preferred to complete the survey over the phone or in person. 


\section{Data analysis}

To determine whether rhino owners had differing demographic characteristics, concerns or opinions from nonowners, we analysed responses based on individuals' current rhino ownership status. We compared the answers of rhino owners and non-owners (excluding respondents who preferred not to disclose their rhino ownership status). For comparisons of nominal variables, we used Fisher's exact test, which corrects for small sample sizes (McDonald, 2009). We also tested for differences in mean responses to statements between rhino owner and non-rhino owner groups (McDonald, 2009).

\section{Results}

\section{Response rate}

We received completed surveys from 169 respondents. We achieved a $100 \%$ response rate during pre-testing and among referrals. Response rates from the Safari Club International convention (18.4\%), Professional Hunters' Association of South Africa membership list (16.4\%), and our compiled list (12.2\%) were lower. Response rates from the two newsletters cannot be calculated because we do not know how many potential respondents received the link to the survey.

\section{Characteristics of the sample}

Nearly all respondents (95.3\%) were male and the median age was $46-55$ years. There was no significant difference in gender (Fisher's exact test, $\mathrm{P}=0.619)$ or age $(\mathrm{P}=0.324)$ between rhino owners and non-rhino owners.

The majority of respondents offered at least one form of hunting on their ranches (86.6\% trophy hunting; $57.3 \%$ biltong hunting; Table 1). Approximately half of all respondents engaged in at least one form of live wildlife sale $(53.0 \%$ of plains game; $48.5 \%$ of rare species and/or colour variants). Nearly $40 \%$ of respondents engaged in photographic tourism and wildlife meat production. Respondents derived the largest share of their wildlife-based income from trophy hunting (46.7\%). Non-owners derived a larger share of their wildlife-based income from trophy hunting than owners $(t=-2.71, \mathrm{P}=0.008)$, whereas owners derived more than non-owners from live sales of rare species and colour variants $(t=3.50, \mathrm{P}=0.001$; Table 1$)$.

The distribution of annual, pre-tax incomes for respondents was approximately U-shaped, with $24.9 \%$ of all respondents (including respondents who preferred not to state whether they owned rhinos) earning $<$ ZAR 1 million (USD 76,000) in pre-tax income and $20.1 \%$ of all respondents earning $>$ ZAR 7 million (USD 532,000) in pre-tax income (Fig. 1). Rhino owners had significantly higher incomes than non-rhino owners (Fisher's exact test, $\mathrm{P}=0.002$ ).

Nearly a third (32.0\%) of all respondents owned, leased, and/or managed $>5,000$ ha of land, whereas $18.3 \%$ owned 1,001-2,000 ha, $11.2 \%$ owned 2,001-3,000 ha. and $11.2 \%$ owned 3,001-4,00o ha. Rhino owners owned significantly more land than non-rhino owners (Fisher's exact test, $\mathrm{P}=0.020)$. The majority $(52.7 \%)$ of all respondents owned, leased, and/or managed land in Limpopo province. The per cent of respondents who owned, leased, and/or managed land in other provinces ranged from 2.3\% (Mpumalanga) to 17.5\% (Eastern Cape). A subset of respondents owned, leased or managed land in multiple provinces.

\section{Decisions about rhino ownership}

Thirty-three respondents (19.3\%) stated that they currently own rhinos. A total of 20 rhino owners $(>60 \%$ of owners surveyed) dehorned their rhinos.

Both rhino security costs (e.g. salaries and accommodation for guards, equipment) and management costs (e.g. supplemental feed, dehorning, insurance, management plan/consulting, and permit costs) were sizeable monthly expenditures. Security costs tended to exceed management costs (Fig. 2). Aggregate expenditures across respondents indicated that rhino owners spend at least ZAR 3,600,023 (USD 273,600) per month on security costs and ZAR

TABLE 1 The per cent (and number) of respondents engaged in various wildlife industry activities, the mean per cent of income derived from these activities, and a $t$-test of the difference in mean per cent of income between owners and non-owners.

\begin{tabular}{|c|c|c|c|c|c|c|}
\hline \multirow[b]{2}{*}{ Activity } & \multirow[b]{2}{*}{$\%$ (number) } & \multicolumn{3}{|c|}{ Mean $\%$ of income $\pm S D$} & \multirow[b]{2}{*}{$t$} & \multirow[b]{2}{*}{$\mathrm{P}$} \\
\hline & & All respondents* & Owner & Non-owner & & \\
\hline Trophy hunting & $86.6 \%(148)$ & $46.7 \pm 32.67$ & $33.6 \pm 27.26$ & $50.6 \pm 32.64$ & -2.71 & 0.008 \\
\hline Biltong hunting & $57.3 \%(98)$ & $11.7 \pm 17.01$ & $8.8 \pm 13.38$ & $13.0 \pm 18.17$ & -1.23 & 0.220 \\
\hline Live sales plains game & $53.0 \%(92)$ & $9.3 \pm 14.94$ & $12.3 \pm 17.25$ & $7.8 \pm 12.32$ & 1.62 & 0.107 \\
\hline Live sales rare species & $48.5 \%(84)$ & $17.0 \pm 27.54$ & $31.5 \pm 34.91$ & $12.8 \pm 23.39$ & 3.50 & 0.001 \\
\hline Ecotourism & $39.8 \%(68)$ & $7.1 \pm 15.38$ & $6.6 \pm 11.86$ & $6.2 \pm 13.45$ & 0.17 & 0.865 \\
\hline Game meat & $37.4 \%(64)$ & $2.9 \pm 4.77$ & $3.1 \pm 3.81$ & $3.1 \pm 5.15$ & 0.01 & 0.992 \\
\hline
\end{tabular}

${ }^{\star}$ Includes survey respondents who preferred not to state whether they owned rhinos. 


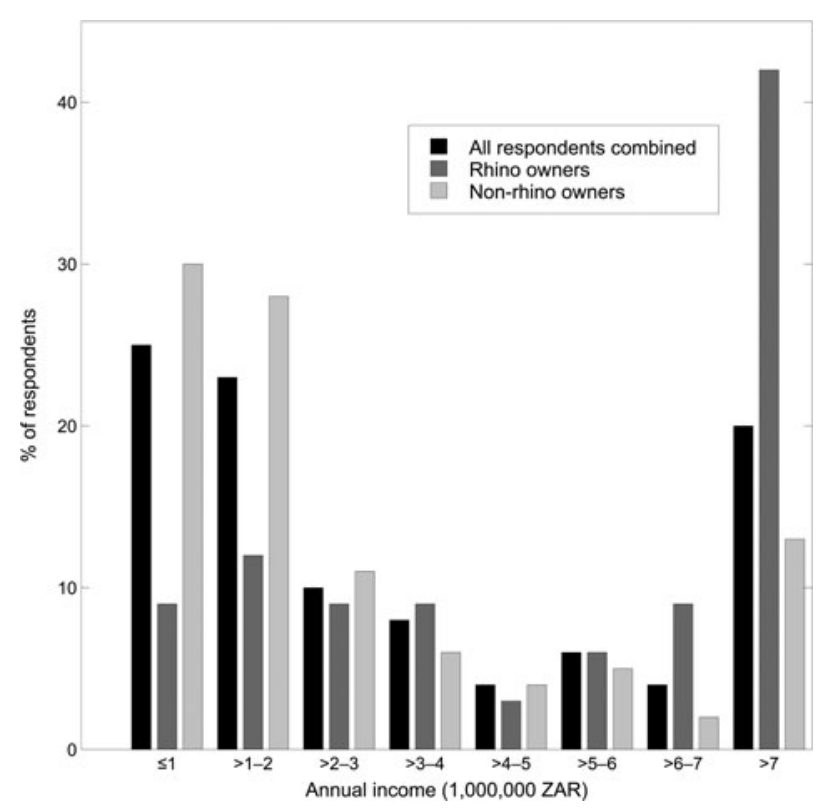

FIG. 1 Per cent of all respondents combined, of rhino owners and of non-rhino owners in annual pre-tax income groups (ZAR $1 \approx$ USD 0.076 in 2017).

2,900,016 (USD 220,400) per month on management costs. On average, surveyed rhino owners incurred c. ZAR 109,100 (USD 8,290) per month in security costs and ZAR 87,900 (USD 6,680) per month in management costs (Fig. 2). There was no significant relationship between land size and security (Fisher's exact test $=0.944$ ) or management costs (Fisher's exact test $=0.580$ ).

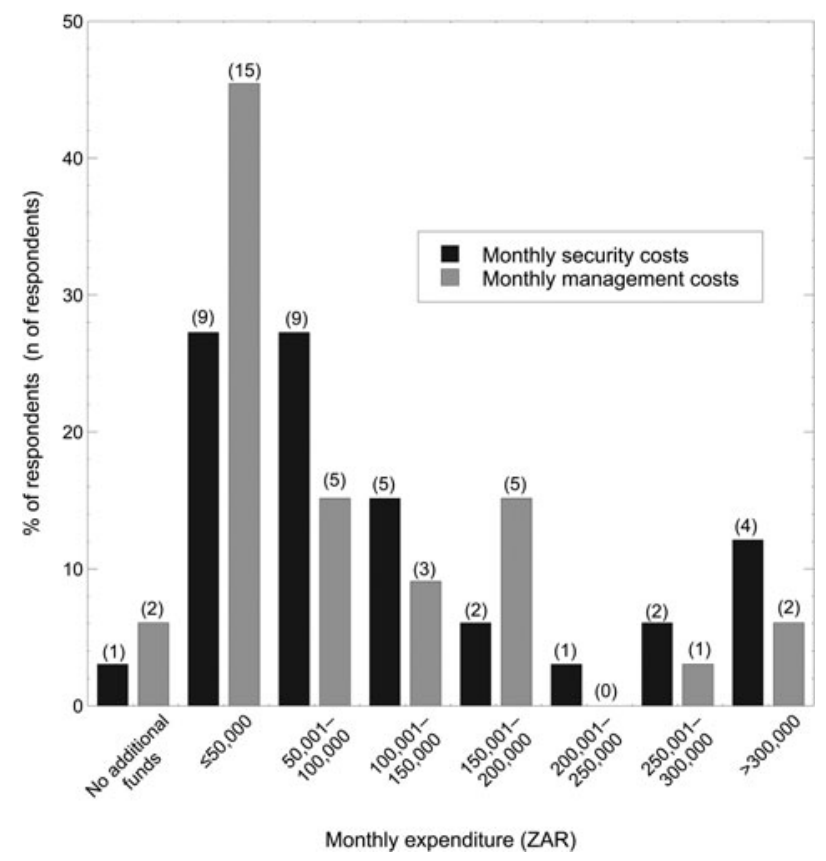

FIG. 2 Per cent of respondents' monthly security and management costs associated with rhino ownership by monthly expenditure group ( $1 \mathrm{ZAR} \approx \mathrm{USD} 0.076$ in 2017).
The majority of rhino owners indicated that their financial costs always (69.7\%) or almost always (15.2\%) exceed the revenues generated from rhinos. Fewer owners stated that their financial costs sometimes (9.1\%) or rarely $(6.1 \%)$, exceed revenues generated from rhinos. No owners stated that these costs never exceed revenues. Median responses regarding the level of concern about risks associated with rhino ownership (on a scale of $1=$ not at all concerned to 4 = very concerned) were that respondents were very concerned about rhinos being poached, government decisions related to rhino ownership, and the safety of their family and employees (Table 2).

As a result of the substantial expenses and risks associated with rhino ownership, the majority of rhino owners admitted that they either frequently $(54.6 \%)$ or occasionally (24.2\%) consider removing rhinos from their lands. Only a small portion of rhino owners stated that they rarely (9.1\%) or never $(12.1 \%)$ consider removing their rhinos. When asked why they continue to keep rhinos, owners mostly cited a passion for rhino conservation (94.0\%). Other key reasons for rhino ownership included that rhinos are attractive to visitors $(57.6 \%)$, that respondents want to have as many native species possible on their lands (45.5\%), and that respondents consider rhino horn to be a potentially valuable investment $(45.5 \%)$. Less common reasons for rhino ownership included that respondents wanted to have the Big Five (lion Panthera leo, leopard Panthera pardus, elephant Loxodonta africana, Cape buffalo Syncerus caffer and rhinoceros) on their land (27.3\%), that rhinos serve as good grazers and/or browsers for the land (24.2\%), and that they offer rhino hunting (24.2\%).

The median response of those who did not own rhinos $(n=112)$ or preferred not to state whether they owned rhinos $(n=24)$ regarding their level of concern about rhino ownership (Table 2) was 'very concerned' about rhinos being poached, government decisions related to rhinos, and safety risks to their families. Of these 136 respondents, 33 had owned rhinos in the past. When asked why they no longer own rhinos, these respondents primarily cited the dangers of poaching (39.4\%), past poaching events (33.3\%), and the high financial cost of rhino ownership (18.2\%).

\section{Respondents' attitudes towards government}

The majority of respondents thought that interacting with the Department of Environmental Affairs either definitely $(51.8 \%)$ or probably $(25.9 \%)$ increases the risk of poaching events. Beliefs about provincial government were similar, with most respondents stating that interacting with their provincial environmental department definitely $(46.1 \%)$ or probably $(27.5 \%)$ increases the risk of poaching. Other respondents were unsure of this linkage, with $14.5 \%$ and $18.0 \%$ of respondents believing that interacting with the 
TABLE 2 Expressed level of concern (as \% of each risk factor) of rhino owners and other respondents about the risks of rhino ownership on a scale of 1 (not at all concerned)-4 (very concerned), with median and mean level of concern.

\begin{tabular}{|c|c|c|c|c|c|c|}
\hline Risk factor & $\begin{array}{l}\text { Not at all concerned } \\
(\%)\end{array}$ & $\begin{array}{l}\text { A little concerned } \\
(\%)\end{array}$ & $\begin{array}{l}\text { Concerned } \\
(\%)\end{array}$ & $\begin{array}{l}\text { Very concerned } \\
(\%)\end{array}$ & Median & Mean \pm SD \\
\hline \multicolumn{7}{|l|}{ Rhino owners $(\mathrm{n}=33)$} \\
\hline Rhinos being poached & 3.0 & 0.0 & 6.1 & 90.9 & 4 & $3.9 \pm 0.56$ \\
\hline Government decisions & 0.0 & 6.1 & 18.2 & 75.8 & 4 & $3.7 \pm 0.58$ \\
\hline Safety of family & 0.0 & 6.1 & 24.2 & 69.7 & 4 & $3.6 \pm 0.59$ \\
\hline Safety of employees & 9.1 & 6.1 & 12.1 & 72.7 & 4 & $3.5 \pm 0.96$ \\
\hline Safety of guests & 12.1 & 33.3 & 18.2 & 36.4 & 3 & $2.8 \pm 1.07$ \\
\hline \multicolumn{7}{|c|}{ Other respondents ${ }^{\star}(n=136)$} \\
\hline Rhinos being poached & 6.6 & 2.2 & 10.3 & 80.9 & 4 & $3.7 \pm 0.82$ \\
\hline Government decisions & 10.3 & 6.6 & 18.4 & 64.7 & 4 & $3.4 \pm 0.99$ \\
\hline Safety of family & 12.5 & 9.6 & 18.4 & 59.6 & 4 & $3.3 \pm 1.06$ \\
\hline Safety of employees & 16.9 & 12.5 & 24.3 & 46.3 & 3 & $3.0 \pm 1.12$ \\
\hline Safety of guests & 19.1 & 11.8 & 22.1 & 47.1 & 3 & $3.0 \pm 1.16$ \\
\hline
\end{tabular}

${ }^{*}$ Includes non-rhino owners and respondents who preferred not to state whether they owned rhinos.

Department of Environmental Affairs or their provincial department, respectively, may increase the risk of poaching. Only $7.8 \%$ and $8.4 \%$ of respondents believed that interacting with the Department of Environmental Affairs and their provincial environmental department, respectively, probably or definitely does not increase the risk of poaching. When comparing the responses of rhino owners and nonrhino owners (excluding respondents who preferred not to disclose their current rhino ownership status), there was no statistical difference between rhino owners and non-owners with regards to their beliefs about the risks of interacting with the Department of Environmental Affairs (Fisher's exact test, $\mathrm{P}=0.451$ ) or provincial environmental departments $(\mathrm{P}=0.327)$.

The mean level of concern regarding whether land reform may negatively impact their wildlife operations (on a scale of $1=$ not at all concerned to $4=$ very concerned) was $3.39 \pm$ SD 0.90). There was no significant difference in the mean level of concern between rhino owners (3.21 \pm SD 0.96) and non-owners $(3.46 \pm \mathrm{SD} 0.85)(t=-1.37, \mathrm{P}=0.173)$.

\section{Respondents' attitudes towards global horn trade legalization}

The majority of respondents strongly agreed that legalizing the global rhino horn trade would benefit rhino owners $(81.9 \%)$, benefit rhino conservation (81.3\%), and reduce rhino poaching (63.2\%; Table 3$)$. Although the majority of respondents $(62.6 \%)$ strongly agreed that it would be acceptable if horn trade legalization led to intensive rhino farming, they also agreed $(36.3 \%)$ or strongly agreed $(42.7 \%)$ that there should be a minimum land size requirement for participation in the horn trade market, to incentivize habitat conservation. We found a significant difference between rhino owners and non-owners with regards to their beliefs that legalization will benefit rhino owners (Fisher's exact test, $\mathrm{P}=0.006)$ and rhino conservation $(\mathrm{P}=0.011)$, with rhino owners showing more support for both of these statements (Table 3).

\section{Discussion}

Similar to Taylor et al. (2015), we relied on multiple methods to recruit survey participants because new privacy laws protect government and industry organization membership lists. Our response rates were similar to those achieved by Lindsey et al. (2006) and van der Waal \& Dekker (2000). Surveys on sensitive topics tend to suffer from higher levels of nonresponse bias (de Leeuw et al., 2008), and we therefore expected difficulties in recruiting respondents given the subject of our survey (Davies-Mostert, 2014; Wright et al., 2016).

Although our sample size of 33 rhino owners is small, this accounts for c. $10 \%$ of rhino owners in the country (CITES Management Authority, 2016). Compared to non-owners, we found that rhino owners have significantly higher incomes and landholdings. They also derive less of their income from trophy hunting and more of their income from live sale of valuable game species. The breeding of high value species (rare species and colour variants) may provide rhino owners with the income needed to finance rhino ownership as the prices of high value species may reach hundreds of thousands of dollars (Taylor et al., 2015).

Although studies reference the substantial financial burden of anti-poaching costs for private landowners (Ferreira et al., 2014; Collins et al., 2016), our study is the first to estimate these costs. Rhino owners in our sample spend a mean of c. ZAR 109,100 per month on security costs and ZAR 87,900 per month on management costs. As dehorning costs (which were included in management costs for this 
TABLE 3 Responses to five statements (as \% per statement) regarding global horn trade legalization, with probability of Fisher's exact test comparing rhino owners to non-owners.

\begin{tabular}{|c|c|c|c|c|c|}
\hline Statement & Answer & $\begin{array}{l}\text { All respondents } \\
(\mathrm{n}=169)\end{array}$ & $\begin{array}{l}\text { Owner } \\
(\mathrm{n}=33)\end{array}$ & $\begin{array}{l}\text { Non-owner } \\
(\mathrm{n}=112)\end{array}$ & $\mathrm{P}$ \\
\hline \multirow{5}{*}{$\begin{array}{l}\text { I believe legalizing the global horn trade will benefit } \\
\text { rhino owners }\end{array}$} & Strongly agree & 81.9 & 91.0 & 77.7 & \multirow[t]{5}{*}{0.006} \\
\hline & Agree & 15.8 & 3.0 & 21.4 & \\
\hline & Neither agree nor disagree & 1.2 & 3.0 & 0.9 & \\
\hline & Disagree & 0.6 & 3.0 & 0.0 & \\
\hline & Strongly disagree & 0.6 & 0.0 & 0.0 & \\
\hline \multirow{5}{*}{$\begin{array}{l}\text { I believe legalizing the global horn trade will benefit } \\
\text { rhino conservation }\end{array}$} & Strongly agree & 81.3 & 97.0 & 75.9 & \multirow[t]{5}{*}{0.011} \\
\hline & Agree & 17.0 & 3.0 & 23.2 & \\
\hline & Neither agree nor disagree & 1.2 & 0.0 & 0.9 & \\
\hline & Disagree & 0.0 & 0.0 & 0.0 & \\
\hline & Strongly disagree & 0.6 & 0.0 & 0.0 & \\
\hline \multirow{5}{*}{$\begin{array}{l}\text { I believe legalizing the global horn trade will reduce } \\
\text { rhino poaching }\end{array}$} & Strongly agree & 63.2 & 81.8 & 56.3 & \multirow[t]{5}{*}{0.090} \\
\hline & Agree & 29.2 & 15.2 & 33.9 & \\
\hline & Neither agree nor disagree & 3.5 & 3.0 & 4.5 & \\
\hline & Disagree & 2.9 & 0.0 & 4.5 & \\
\hline & Strongly disagree & 1.2 & 0.0 & 0.9 & \\
\hline \multirow{5}{*}{$\begin{array}{l}\text { It would be acceptable to me if global horn trade } \\
\text { legalization led to intensive rhino farming }\end{array}$} & Strongly agree & 62.57 & 66.7 & 58.0 & \multirow[t]{5}{*}{0.721} \\
\hline & Agree & 29.24 & 24.2 & 33.9 & \\
\hline & Neither agree nor disagree & 2.34 & 3.0 & 2.7 & \\
\hline & Disagree & 4.68 & 6.1 & 5.4 & \\
\hline & Strongly disagree & 1.17 & 0.0 & 0.0 & \\
\hline \multirow{5}{*}{$\begin{array}{l}\text { I think there should be a minimum land } \\
\text { requirement to participate in a legal horn market } \\
\text { so that horn trade results in wildlife habitat } \\
\text { conservation }\end{array}$} & Strongly agree & 42.7 & 45.5 & 42.0 & \multirow[t]{5}{*}{0.906} \\
\hline & Agree & 36.3 & 36.4 & 37.5 & \\
\hline & Neither agree nor disagree & 9.4 & 9.1 & 9.8 & \\
\hline & Disagree & 7.0 & 3.0 & 7.1 & \\
\hline & Strongly disagree & 4.7 & 6.1 & 3.6 & \\
\hline
\end{tabular}

${ }^{\star}$ Includes survey respondents who preferred not to state whether they owned rhinos.

study) could be considered security costs, our estimates of security costs may be an underestimate of the true financial costs of protecting rhinos. These monthly expenditures provide insight into why $69.7 \%$ of owners stated that rhino-related costs exceed the revenues from owning rhinos. Wright et al. (2016) also found that rhino owners and land managers were concerned that the costs of protecting rhinos undermined the financial viability of their reserves. For our study, only $45 \%$ of owners considered rhinos to be a good future financial investment in terms of the value of their horn, although $58 \%$ stated they were attractive to visitors, which may translate into higher tourism revenues. The prevailing reason for rhino ownership was a passion for rhino conservation, which is an inherently non-financial motivation for rhino ownership (Rubino \& Pienaar, 2018).

All respondents, regardless of rhino ownership, provided identical ranking of the risks associated with owning rhinos, expressing the greatest concern about the risks of rhinos being poached and government decisions related to rhino ownership. This indicates that non-owners recognize the main risks of rhino ownership. Respondents' concerns about poaching threats are consistent with our finding that previous owners removed rhinos from their land because it put their ranches in danger of poaching. Our finding that both rhino owners and non-owners are concerned about how the presence of rhinos on their properties affects the safety of their families is consistent with the findings of Wright et al. (2016).

The belief of the majority of respondents that interacting with the Department of Environmental Affairs and provincial environmental departments increased poaching risks is consistent with a few documented cases of corruption of South African national and provincial conservation officials and members of the police force by the illegal rhino horn trade, and arrests of government employees related to rhino poaching (Montesh, 2013; Rademeyer, 2016). Lack of trust in government may be further reinforced by land reform in South Africa, which is an emotional and controversial political issue, and there are significant societal divisions regarding the implementation of land reform (Sebola \& Tsheola, 2014).

Our respondents' positive attitudes towards the legalization of rhino horn trade are consistent with documentation of the attitudes of rhino owners and other wildlife-industry stakeholders towards rhino horn trade. Nine of 10 rhino owners and six of 15 reserve managers interviewed by Wright et al. (2016) either strongly agreed or agreed that horn trade should be legalized. Similarly, a polling question 
by the Private Rhino Owners Association of South Africa found that $85 \%$ of its members supported horn trade legalization in 2015 (Jones, 2017a).

We found that $97.7 \%$ of respondents agreed that legalizing the global rhino horn trade would benefit rhino owners. Wright et al. (2016) found that $84 \%$ of their 25 respondents believed that legalization would result in additional income to rhino owners and $60 \%$ believed it would increase the value of live rhinos. Although $98.3 \%$ of our respondents agreed that legalization would benefit rhino conservation, only $64 \%$ of Wright et al.'s (2016) respondents believed legalization would better protect rhinos, $56 \%$ believed it would result in an expanded rhino range, and $40 \%$ believed it would result in increased rhino populations. We also found that $92.4 \%$ of respondents agreed that legalization would reduce rhino poaching, whereas only $20 \%$ of Wright et al.'s (2016) respondents believed legalization would reduce the incentive to poach.

Although $91.8 \%$ of our respondents agreed that it would be acceptable if horn trade legalization led to intensive rhino farming, $79 \%$ of our respondents also agreed that participation in the horn trade should require a minimum land size per rhino to ensure increased habitat conservation. This indicates that these two ideas are not mutually exclusive. This may be because respondents do not believe that legalizing the trade in horn will result in large-scale, intensive rhino farming. Additionally, rhino owners in our sample managed or owned larger areas of land than non-owners. Thus, respondents may be of the opinion that rhino owners (or potential rhino owners) probably have sufficient land to fulfil any minimum land requirement.

\section{Conclusion and policy implications}

Understanding the perspectives of current and potential rhino owners about legalizing the trade in rhino horn is important because they will be directly affected by any changes in policy on horn trade (Wright et al., 2016) and have a key role to play in rhino conservation as the stewards of a third of South Africa's rhino population (Rademeyer, 2016). Although, given our small sample size, we caution against using our findings to make inferences for all rhino owners and the wildlife ranching community of South Africa, we are able to provide some useful insights into decision-making by rhino owners. Understanding the characteristics of rhino owners (e.g. higher income individuals, high-value species breeders) is important when generating policies to incentivize rhino conservation. Our estimates of ranch-scale security and management costs indicate that rhino owners are making a substantial financial contribution to rhino conservation, without receiving any government or conservation agency funding in return (Child, 2012). They are also bearing non-financial burdens in terms of concerns for the safety of their families and employees. Documenting the financial and non-financial costs that rhino owners bear is important for understanding why they may support the legalization of the trade in rhino horn. Such support may be driven by the need to cover the costs of rhino security and management to keep rhinos on private lands (Child, 2012; Biggs et al., 2013).

Understanding the perspectives of wildlife ranchers who do not own rhinos, who were also broadly supportive of legalization of global horn trade, is important because these ranchers, who have already invested in the wildlife industry, may be incentivized to participate in rhino conservation. These individuals already have wildlife ranches and the required infrastructure, but may also need the assurance that they can earn sufficient income to cover the costs of rhino ownership. Their support of the legalization of global horn trade suggests that legalization may be the incentive required for participation in rhino ownership and conservation. In addition, although respondents were not opposed to intensive rhino farming, they were also largely supportive of minimum land requirements for rhino owners who wish to engage in horn trade. This indicates that there is potential for trade in rhino horn to be a driver of conservation of habitat and other wildlife that coexists with rhinos.

Although the effect of the 2017 legalization of domestic rhino horn trade on rhino conservation is not yet known, our results suggest that this may be an important incentive to keep rhinos on private lands, by allowing ranchers to defray the costs of rhino ownership. There is, however, opposition to legalization of the horn trade, by conservation interest groups who consider this trade to be unethical and/or potentially detrimental to rhino conservation (Wright et al., 2016). We have not covered these issues but rather have sought to document the realities of rhino ownership on private lands, and why rhino owners and other wildlife industry members in South Africa support the trade in rhino horn. Understanding their opinions and constraints is important for the design of policy and for debate about legalization of the rhino horn trade.

Acknowledgements We thank all respondents for completing the survey, the Professional Hunters' Association of South Africa and the South African Hunters and Game Conservation Association for disseminating the survey, and the Dallas Safari Club Foundation for funding this study. This Foundation had no involvement in the research design and implementation, or data analysis. We thank Brian Child and Lyn Branch for their critiques.

Author contributions Lead on research design, survey implementation and data analysis: ECR; contributions to research design, data analysis and writing: EFP.

\section{Conflicts of interest None.}

Ethical standards The survey was approved by the University of Florida Institutional Review Board (IRB201601671). 


\section{References}

Alaimo, K., Olson, C.M. \& Frongillo, E.A. (1999) Importance of cognitive testing for survey items: an example from food security questionnaires. Journal of Nutrition Education, 31, 269-275.

BieRNACKI, P. \& WALDORF, D. (1981) Snowball sampling: problems and techniques of chain referral sampling. Sociological Methods \& Research, 10, 141-163.

Biggs, D., Courchamp, F., Martin, R. \& Possingham, H.P. (2013) Legal trade of Africa's rhino horns. Science, 339, 1038-1039.

Child, B. (2012) The sustainable use approach could save South Africa's rhinos. South African Journal of Science, 108, 21-25.

Cites Management Authority (2016) Rationale for Swaziland's proposal to CITES to legalize trade in its rhino horn. Information document for amendment proposal $\mathrm{CoP}_{17}$ Prop. 7 ( $\mathrm{CoP}_{17}$ Inf. 17). The Kingdom of Swaziland's Big Games Parks, CITES Management Authority. Https://biggameparks.org/img/cms/tabs/CITES\% 20CoP17\%20INFO\%20DOC\%2028\%20pg\%20-\%20SWAZILAND_ 3.pdf [accessed 10 August 2017].

Collins, A., Fraser, G. \& Snowball, J. (2016) Issues and concerns in developing regulated markets for endangered species products: the case of rhinoceros horns. Cambridge Journal of Economics, 40, 1669-1686.

Cousins, J., Sadler, J. \& Evans, J. (2008) Exploring the role of private wildlife ranching as a conservation tool in South Africa: stakeholder perspectives. Ecology and Society, 13, 43.

Davies-Mostert, H.T. (2014) Overcoming barriers to understanding the biodiversity contribution of private ranchlands. Animal Conservation, 17, 399-400.

De Leeuw, E.D., Hox, J.J. \& Dillman, D.A. (2008) International Handbook of Survey Methodology. Taylor \& Francis, New York, USA.

Ferreira, S.M., Pfab, M. \& Knight, M. (2014) Management strategies to curb rhino poaching: alternative options using a cost-benefit approach. South African Journal of Science, 110, 1-8.

Jones, P. (2017a) Rhino Horn Moratorium-Constitutional Court Judgement. Private Rhino Owners Association: Media Release. Http://www.rhinoalive.com/wp-content/uploads/2017/04/ PROA-media-statement-Concourt-Judgement-05-04-2017.pdf [accessed 18 May 2017].
Jones, P. (2017b) Private Rhino Owners Association Newsletter, April 2017. Http://www.rhinoalive.com/wp-content/uploads/2017/ 04/PROA-Newsletter-April-2017.pdf [accessed 22 June 2017].

Lindsey, P.A., Alexander, R., Frank, J.G., Mathieson, A. \& Romanach, S.S. (2006) Potential of trophy hunting to create incentives for wildlife conservation in Africa where alternative wildlife-based land uses may not be viable. Animal Conservation, 9, 283-291.

McDonald, J.H. (2009) Handbook of Biological Statistics, 2nd edition. Sparky House Publishing, Baltimore, USA.

Montesh, M. (2013) Rhino poaching: a new form of organised crime. Unpublished report. College of Law Research and Innovation Committee of the University of South Africa, Pretoria, South Africa. Http://www.rhinoresourcecenter.com/pdf_files/136/1368077595.pdf [accessed 7 August 2017].

Pienaar, E.F., Rubino, E.C., Saayman, M. \& van der Merwe, P. (2017) Attaining sustainable use on private game ranching lands in South Africa. Land Use Policy, 65, 176-185.

Rademeyer, J. (2016) Tipping Point: Transnational Organised Crime and the 'War' on Poaching. Global Initiative against Transnational Organized Crime, Geneva, Switzerland.

Rubino, E.C. \& Pienaar, E.F. (2018) Understanding South African private landowner decisions to manage rhinoceroses. Human Dimensions of Wildlife, 23, 160-175.

Sebola, M.P. \& Tsheola, J.P. (2014) Economics of agricultural land restitution and redistribution in South Africa: willing-seller, willing-buyer business imperatives versus socio-political transformation? Journal of Human Ecology, 46, 113-123.

Taylor, A., Lindsey, P. \& Davies-Mostert, H. (2015) An Assessment of the Economic, Social and Conservation Value of the Wildlife Ranching Industry and its Potential to Support the Green Economy in South Africa. The Endangered Wildlife Trust, Johannesburg, South Africa.

VAN DER WAAL, C., \& DeKKer, B. (2000) Game ranching in the northern province of South Africa. South African Journal of Wildlife Research, 30, 151-156.

Wright, O.T., Cundill, G. \& Biggs, D. (2016) Stakeholder perceptions of legal trade in rhinoceros horn and implications for private reserve management in the eastern cape, South Africa. Oryx, $52,175-185$. 